\title{
THE CONSUMPTION AND TRANSFORMATION OF RESORT HOTELS
}

\author{
S. DOGANER \\ College of Architecture, University of Texas at San Antonio, San Antonio, Texas, USA.
}

\begin{abstract}
Changes in the economic, political, social, cultural, and organizational areas have, apparently, changed and altered the demands of consumers of resort hotels. It clearly can be observed that it is no longer sufficient merely to meet the need for accommodations. Besides that consumers expect more in the way of entertainment, adventure, and boundless facilities, and as a result, resorts aim to make consuming something to enjoy. Resort hotels host an endless variety of functions, set up temporary experiences, and frequently make changes to the types of consumption they offer. To meet consumer and tour operators' expanding demands, to increase their market share and ensure repeat business, to keep up with recent developments in management, technology, and design, to adhere to international environmental standards, provide new, popular, and different experiences, and ultimately to survive in this environment, resort hotels have to transform.

This research discusses the consumption of tourist spaces, and the transformation of resort hotels through new additions and renovations. It analyses changing tendencies and design principles, new functional and spatial necessities, and the ever-evolving design process. In a case study of Antalya/Turkey, this research examines the reasons for and results of these changes, explores the spaces created by these transformations, and develops proposals for building a more conscious approach to the overall design process. In this framework, designers are called to envision this temporariness beforehand and reflect it in their designs, developing flexible designs that more easily comply with the shifting needs of tourist consumers. This need for flexibility and continuous transformation of functional spaces indicates that this new building typology should be redefined. As a result, the architect is challenged to search for design quality, uniqueness, and flexibility, while simultaneously accommodating the constantly changing nature of design input, as well as the functional and spatial requirements of resort hotels.
\end{abstract}

Keywords: Architecture, consumption, design, renovation, resort hotel, sustainability, transformation.

\section{INTRODUCTION}

Tourism is usually defined as social and economical activities engaged in during leisure time or while on vacation. According to Lawson, tourism offers individuals the opportunity to enjoy and learn about different cultures, discover moments in history and investigate new places, and have fun while traveling [1]. Tourism is not simply a grouping of different commercial activities; it involves an individual's ideologies about history, culture, nature, and tradition. These ideologies can become so powerful that they can change culture and nature of the areas they touch to make the visited area fit their idea of what that space should be [2].

By the second half of the twentieth century, significant social, economic, and political shifts in the world caused drastic changes in the global tourism industry, causing the focus to be shifted toward a consumption-based form of mass tourism. After this historical turning point, the general profile of tourists, their expectations and demands, mutated. This change has transformed the so-called subject tourist (who makes individual visits especially for the purpose of cultural tourism) to a statistical tourist, the object of the 'package' holiday. Tourism has become a single activity, sold at a fixed price, and usually earmarked by all-inclusive tours, crowded airports, and group travel. These days, when people think of themselves engaging in tourism, a great majority imagine collective visits for the purpose of entertainment [3]. In the common tourist experience, 
Table 1: Systematic changes in tourism.

\begin{tabular}{lll}
\hline Individual tourism & $\begin{array}{l}\text { Mass tourism } \\
\text { Package holidays } \\
\text { Subject tourist }\end{array}$ & $\begin{array}{l}\text { Organized masses } \\
\text { Statistical tourist } \\
\end{array}$ \\
\hline
\end{tabular}

visual images are rapidly consumed; tourists are encouraged to experience numerous different activities and games such that 'tourism centers' have evolved into 'consumer centers' (Table 1).

This evolution in the economic, political, social, cultural, and organizational areas of life has led to resort hotels scrambling to answer the resulting constant desire for consumption and transformation within the resort hotel space. Resort hotels have found it more and more challenging to meet consumer and tour operators' expanding demands, to increase their market share and ensure repeat business, to keep up with recent developments in management, technology, and design, to adhere to international environmental standards, and to provide the new, popular, and different experiences and spaces that tourists have come to expect (and resort hotels have to offer) in order to survive [4].

This research discusses the consumption of various tourist spaces and the transformation of resort hotels by new additions and renovation. By analyzing the changing tendencies and design principles, the new functional and spatial necessities, and the ever-evolving design processes, one can see the need for finding economically and spatially sustainable, unique, and flexible design solutions in this competitive and constantly changing environment.

The rapid consumption and transformation of resort hotels have been analyzed in this research through a case study of 12 resort hotels that were renovated in Antalya/Turkey - a Mediterranean resort city - between 2001 and 2012. This article then discusses the need for a new typology for resort hotels as they move from more traditional services to innovative new areas such as organizing temporary experiences, while accommodating the constantly shifting nature of design input and functional and spatial requirements.

\section{CONSUMPTION OF TOURIST SPACES}

Tourism always has a leading and transforming power on architecture and urban space. Today $63 \%$ of the daily tourism activities are based on exploring the historical and famous buildings and experiencing urban spaces [5]. The spaces, objects, visual images, and themes created in this sense are quickly consumed by the organized masses.

Consumption as part of tourism is a very complex and selective process. Tourism is derived of our anticipation to be astonished by different scales or sensations usually experienced. The places are chosen to be involved in the tourism activity by 'looking at' or 'gazing upon' objects, places, landscapes, and so on, and to experience the new and different [6].

Consumption is a practice that reflects the limitations and opportunities of modern time; it consists of a selection process that is influenced by social, cultural, and economic values [7]. By contrast, Baudrillard expresses that there is no limitation on consumption, and somehow people would like to consume more and more easily [8].

Consuming places are global and they define their own space without any belongings, context and/ or geographical border [9]. They have the ability to manipulate time or in other words, they can create their own era. According to Zengel, "New consuming places simulated to boost consuming. Such places protect and divide consumers' inner sense from outside world. Places such as fun are being consumed easily, and they are usually designed as 'Dream Worlds"' [10]. 
A critical feature of consumption in our time is the need for a holiday. The ability to buy time to avoid work and replace it with other kinds of activities is viewed as a characteristic of health and well being [6].

Today visual identities are consumed without question as most of the aspects of social life that have been aestheticized. Purchasing and consuming an image has become widespread especially in tourism activities. Additionally, it has become more pervasive between the 'new middle class' in many different contexts and cultures [6].

Within the concept of the modern era, the image of the consuming products reflects the common perception of the consumers: their way of living, their attitude, and their identity. They acquire products to delineate their status and their social classes, define themselves and their roles within society, form and preserve their social presence, and express their thoughts and identities [11]. Basically, there are three factors that drive consumers' choice while making travel plans. These are seeking for luxury and addiction to 'Brand', thinking that luxury and brand are proof of their status, and seeking for comfortableness. As a result of rapid development in transportation and communication, destinations turn into vogue and are a part of social life; image has become the key factor in selection and strengthening of the touristic aspects.

All around the world, cities are thriving to base their economies upon tourism, and turn their destination into a 'vogue'. The cities are trying hard to become dreamscapes of visual consumption as well as presenting the culture, heritage, and architecture authentically to the tourist [12].

MacCannell suggests that the tourists seek for the authenticity but it is not successful because those being 'gazed upon' come to construct artificial sites [2]. Urry claims that the tourist spaces are organized around 'staged authenticity'. Urry also defines the tourists who almost delight the inauthenticity as 'post-tourists'. According to him, these tourists know that the authentic tourist experience does not exist without the tourism input, and any so-called authenticity is a 'pastiched surface feature' of postmodern experience [6].

However, representation of the cities is effective on marketing the authenticity and cultural identity. As understanding ethnicity means a full perception of the tradition, the local culture invites tourist to 'pay to see' its 'realness'. The phenomenon of 'hyper-tradition' is recreated by the local culture [13]. It is visualized in a more pervasive approach in the 'themed' environment. Urry quotes what Eco summarizes as "These apparently real and authentic environments are "travels in hyperreality"... Disneyland tells us that technology can give us more reality than nature can'. Urry states that in these environments tourists are encouraged to gaze upon and consume images and identities of many cultures. He claims "This is made possible by the most extreme form of "time-space compression," what one might term global miniaturization' [6].

Today postmodernism requires global identities and does de-differentiated local cultures. Identities and images are consumed rapidly, and the relationship between representations and reality has become a problematic issue in postmodern cultures. Urry also states 'What is consumed in tourism are visual signs and sometimes simulacrum; and this is what is consumed when we are supposedly not acting as tourists at all' [6].

Disneyland, which has been analyzed by Jean Baudrillard, is a perfect model of all the entangled orders of simulacra. He claims, "It is first of all a play of illusion and phantasm. Disneyland exists in order to hide that it is the "real" country, all of "real" America that is Disneyland. Disneyland is presented as imaginary in order to make us believe that the rest is real, whereas all of Los Angeles and the America that surrounds it are no longer real, but belongs to the hyper-real order and the order of simulation' [14].

American art critic David Hickey states that Las Vegas has the only 'authentic' image in North America. Las Vegas, which has earned the 'originality' status by collecting various urban and 
architectural symbols from all around the world, gives you the feeling of being 'everywhere, but nowhere' [15]. Post-modern culture of today and the consumer society that emerged as a result of it offers anyone endless freedom in all areas. The theme parks, entertainment and recreation centers, and tourist venues, which provide different experiences in this context form the real and dramatic visual landscapes of consumption [16].

\section{TRANSFORMATION OF RESORT HOTELS}

Today, it is apparent that the demands of consumers of resort hotels have changed and altered; this shift clearly can be observed in that it is generally considered insufficient only to meet the tourist's need of accommodations anymore. Additionally, the consumers of tourist products expect more in the way of entertainment, adventure, and boundless facilities. Sows and attractions now play a key factor in tourists' resort choices, and producers of tourism products aim to make consuming something to enjoy [17].

The development of the tourism industry, a commercial area that is improving rapidly, has progressed in parallel with the development of vacation needs and the expectations of those who seek to spend a portion of their income on their holiday entertainment. Especially after the 1980s, the basic criteria for the design of a resort hotel became 'creating environments for making tourists happy and meeting their expectations' and 'being liked'. Today's consumers want to go far away from their daily routines and gain new and unique experiences on their holidays. This desire creates a point of conflict between popular values and settled, permanent values. No matter how organized, stable, and reliable their lives are in their daily routines, on holiday tourists aspire to have eyecatching, fashionable, and tailor-made vacation experiences; they hope to gain different kinds of experiences, more excitement, and to become temporary parts of other people's lives, to temporarily borrow their images. No doubt the temporarily lifestyle one can experience while on holiday is perceived as more attractive and entertaining than the routine, calm, and permanent life most consumers of tourist products would consider their status quo. Resort hotel guests are neither temporal nor permanent; they are sophisticated consumers who act, play, entertain, eat, and sleep, and want to end their vacations with a revitalized soul and a refreshed brain.

Changes in tourism's flow of supply and demand, as well as political, economic, socio-cultural, organizational, and time-dependent changes in the world, have all worked together to motivate the physical changes now being made to resort hotels, as well as these hotels' overall design principles [4]. All around the world, resort hotels have transformed into 'an architecture of fantasy and escape', and centers of mass pleasure [18]. Today, the new resort hotel goes beyond mere accommodation to triggering a desire for a nomadic life by presenting interesting designs, unique settings, and desirable (if fantastic) temporary lives, all in an effort to consistently meet the continuously changing consumer demand [19].

In this era of consumption, the current trend in resort hotels is to offer variety of choices and 'dream worlds' so that tourists may choose their own temporary vacation lives. Resort hotels are now being seen to offer bolder, colorful, and imaginative designs than any other architectural genre. They compete with each other to provide tourists the physical embodiment of the 'different'. Reimer has suggested that the need for the 'different' is the reason behind the new itineraries, activities, destinations, marketing strategies, and themed environments that have now become commonplace in the resort hotel industry [20].

Among all of the various types of resorts, the themed hotels stand out for aiming most pointedly at leisure and amusement. In this type of hotels, the effort to offer an authentic experience is replaced by a constructed hyper-reality through the re-definition of traditional environments within the context of mass tourism. Thus, architectural and visual representations are thematized, and the 
processes of 'Disneyfication' and 'Las Vegasization' have become common characteristics of resort areas to create the new 'authenticity' [21]. Tsui states that 'Traditions and heritages are no longer place-specific. Nevertheless, few are aware that the borrowed traditions and heritages have now been localized in Las Vegas, and it is precisely the concentration of mimicked heritages and commodified experiences, embodied in a space of spectacle, that creates the city's unique sense of place' [22]. It has been argued that when the simulation superimposes itself upon the inherited reality, possesses that reality and becomes a point of reference itself, it becomes authentic. Las Vegas and Disney World have almost attained the status of originals, and as being 'new' originals they are now both quoted and imitated [15]; the same has become true in Lara, Antalya.

\subsection{Renovations and additions}

Change is an unavoidable fact of today's design cycle. Changes made to the design of resort hotels are an ordinary result of the various other changes experienced by the tourism industry. For existing resort hotels, renovation is inevitable. As different groups of tourists come to frequent particular resort hotels, resort hotels must make renovations to appeal to their different tastes and needs.

Hassanien and Baum [23] defined renovation as being '... the process of retaining or improving the hotel image by modifying the tangible product, due to a variety of reasons, through any changes in the hotel layout (e.g. property structure - new extension) and/or any additions or replacement of materials and furniture, fixture and equipment.'

Resort hotels always need to be updated. Renovations are necessary not only for aesthetic reasons but also for the financial health of hotels. Rutes et al. [24] states that '... hotels frequently alter existing spaces, such as enlarging a successful restaurant, adding an exercise facility or business center, or converting an underutilized discotheque to another use. In cases there is no available space, owners might consider constructing an addition to the existing hotel in order to meet market demands and realize greater profits. Over time hotels lose their luster and styles need to be updated to reflect current tastes. A fresh look to an existing hotel often is essential in order to compete with a new or recently renovated hotel nearby.'

Globally, the standard amount of time that passes before a resort hotel should consider renovation is approximately 10 years. According to Ayik [25], the most important reasons for renovation are (1) to keep room rates high in a competitive environment, (2) to retain bargaining power while dealing with tour operators, (3) to increase market share by offering new, unique products to consumers, and (4) to compete with new and newly renovated resort hotels. The main reasons for renovations and additions are discussed in the following section [4]:

\section{- Being trendy:}

Renovations and additions to resort hotels are necessary in order to keep up with recent developments in technology and design, to keep the hotel appearing fresh to encourage repeat business [26], and to provide the 'new', the 'popular', and the 'different' that so many tourists have come to expect. Resort hotels compete with each other to provide tourists a sense of something different. Reimer suggests that the need for the 'different' is the reason behind the industry's move toward new types of itineraries, activities, destinations, marketing strategies, and themed environments [20].

- Tour operators' demands:

Tour operators motivate resort hotels to renovate their facilities, and demand that owners have new and high-quality resort hotels available for their customers [27]. 
- Changes in the tourist's profile, demographic and types of demands:

A slight change in the profile of the target population for the resort will eventually lead to a need for major changes or renovations at the resort complex. Resort hotels must be designed and renovated to accommodate these changes to tourist profiles and demographics if they hope to meet tourist demands and survive in the market [28].

- Expanding the market with different alternatives:

Research has shown that the current demands placed upon resorts are not limited to the offered accommodations. Consumers are now seeking fun, adventure, and seemingly unlimited activities from their resort. Resorts hotels should offer a variety of alternatives such as congress centers, golf clubs, health and wellness centers, and sports centers if they hope to attract visitors.

- Changes in marketing strategies and a shift to the all-inclusive system:

The shift from Full Board (FB) and Half Board (HB) to an all-inclusive system requires certain changes to resort hotels to increase the profitability of the facility. For instance, architects should motivate visitors to consume less of the free services (rooms, restaurants, and bars) and more of the paid services (health and wellness centers, water sports, golf, and other activities) with their designs.

- Changes in management systems and/or managers:

Constant changes occur in management systems and/or managers due to the rapidly changing nature of the tourism industry. New management often requires new organizational forms, standards, and images in order to expand the new corporate identity.

- Technological innovations:

Technological improvements such as Wi-Fi connections, pay TV, interactive TV, DVDs, and RFID cards are vital if a resort hopes to keep up with technological innovations and increase the comfort level of their guests.

- International standards on health, safety, and quality:

Today, it is impossible for hotels to survive unless they meet internationally approved standards for health, safety, and quality. Increasing tourist demands force managers to continuously improve upon their own internal standards. The main international standards for safety, quality, and environmental management systems are ISO 9000 (Quality Management Systems), ISO 14000 (Environmental Management Systems), and Hazard Analysis and Critical Control Points (HACCP).

- Environmental factors and sustainability:

Growing public interest in ecology leads to renovations that make hotel more environmentally friendly. These improvements include analysis of impact on energy usage and practice of alternative energy sources, sustainable and energy conserving materials, water savings, recycling, and waste decomposition [24].

- Aging:

Even though the renovation life span for a resort hotel generally is considered to be 10 years, lobbies and other public spaces should be renovated in 3- to 5-year cycles, and guestrooms are likely to need renovation every 5-7 years, in order to keep the hotel fresh. Furniture, carpets, bed covers, skirts, sheets, curtains, and other fabric materials should be changed every 5 years [28]. Mechanical systems, up-to-date lighting, new pluming filters and such should also be modernized every 15-25 years [24]. 


\section{A CASE STUDY IN ANTALYA/TURKEY: 2001-2012}

Antalya is Turkey's most popular tourist destination. The city has been considered a very important maritime center throughout history because of its geography and climate. Natural and historical patterns form city's traditional urban character, and it continues to communicate its unique identity, an identity which encompasses thousands of years of archeological value. Situated in the ancient Pamphylia region, Antalya is rich in historic sites and monuments that can be traced to the Hellenistic, Roman, Byzantine, Seljukian and Ottoman periods. Phaselis, Termessos, Side, Aspendos, and Perge are only a few surviving examples that bear witness to the long life of this region.

The population of Antalya began to increase in the 1950s, due to an increase in immigration to the area. Soon after this urbanization, the city's economic structure became inadequate. It was 1953 when the word 'tourism' began to be used in earnest. In that same year, a law promoting the tourism industry was accepted by its Parliament. Since the 1960s, tourism in the Antalya region has been a priority for Turkey, motivated by city's dense natural and historical value. In 1969, the Turkish government defined a 3-km band of the Aegean and Mediterranean as a dedicated tourism region. In 1973, the Ministry of Culture and Tourism prepared the master plan for Antalya. This plan projected a 174,000-bed capacity for the city, by the year 2000. In reality, the number of beds exceeded the target number and reached 230,000 in 2000; today, Antalya has a 385,000-bed capacity.

In 1980, tourism was further encouraged in the area as a new sector of commerce, with both economic and political objectives. The support given to tourism entrepreneurs by the government through the government's decisions regarding tourism planning has accelerated the demand for resort accommodations. Since the 1980s, through their support of foreign investors hoping to benefit from this growing industry, a different development process began. This process was later improved upon through the franchise chain system [4].

Tourism is now the second largest industry in Turkey, attracting a total of 28.6 million visitors per year. Today, the number of tourists visiting Antalya alone has reached 9.6 million visitors per year. Antalya has attracted people from Germany, Russia, Austria, Sweden, the UK, the Netherlands, France, Denmark, Belgium, Norway, Poland, and Ukraine. Germany (27\%) and Russia (26\% - after the collapse of the Soviet Union) now make up 53\% of the market share in tourism [29].

As a result of this rapid growth, tourism construction has enjoyed a significant acceleration, and a great number of hotels and holiday villages have been built on the east and west coasts of Antalya. Local architectural images and forms are often used on the buildings being constructed, but these images are usually left to offer only a picturesque dimension to an overall experience of the area. This approach not only forms a paradox between the 'fake' and 'real' elements of a visit to Antalya, but it also makes the local architecture appear worthless and ordinary. According to Guzer, the 'Local concept' is an element of tourism that is consumed rapidly. Identity has ceased to be a geographical or cultural reality, and instead is injected into a program designed to affect marketing strategies [10]. Another approach, the 'themed resort hotel', was developed in the 2000s in the Lara region of the city. In Lara, physical replicas of historical buildings and/or cities have been built - like in Las Vegas, and a new tourism region has been constructed. However, unlike Las Vegas, these hotels have been built on touristic plots that are lined up in juxtaposition and perpendicular to the sea. Thematic hotels like the Topkapi Palace, Kremlin Palace, Venezia Palace, Titanic de Luxe, Concorde Resort \& Spa, and Mardan Palace were built next to each other, all along the Lara shore, in order to create a simulated environment that would satisfy a consumer culture based on hyper-tourism. Unfortunately, these thematic hotels bear no resemblance to authentic traditions, and are not at all related to the city, its history, its culture, or its climate. Tourism architecture in the region has been left solely to managers' marketing strategies, and the hotels 
themselves have devolved into stage decoration. These thematic hotels may go so far as to offer a Russian tourist the opportunity to have a drink at the 'Kremlin Palace', after which he can sunbathe in 'dreamland'. In this region, resorts have been designed to serve as spaces for the performance of exoticism, a type of staging that requires visitors to be complicit in this performance; they must also play their part [30].

\subsection{Impacts of change on resort hotel design}

Throughout this rapid acceleration in the city's tourism industry, tourist's profile, their demographics, demands and expectations, management systems, and marketing strategies have also evolved. The increasing number of chain hotels has increased Antalya's institutionalization and standardized spatial organization. Tourists expecting an inexpensive vacation and families traveling together have begun to flock to Antalya, especially after tour operators began to take a more active role in marketing and the local resorts expanded to incorporate an all-inclusive accommodation system (Table 2).

Table 2: Changes in tourism and the impacts of such change on resort hotel design [4].

\begin{tabular}{|c|c|c|}
\hline & Areas of change & Impacts of change on resort hotel design \\
\hline 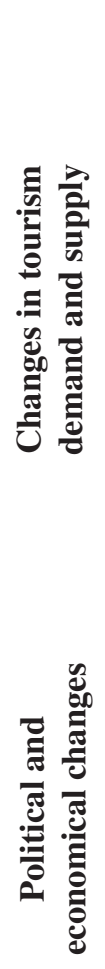 & 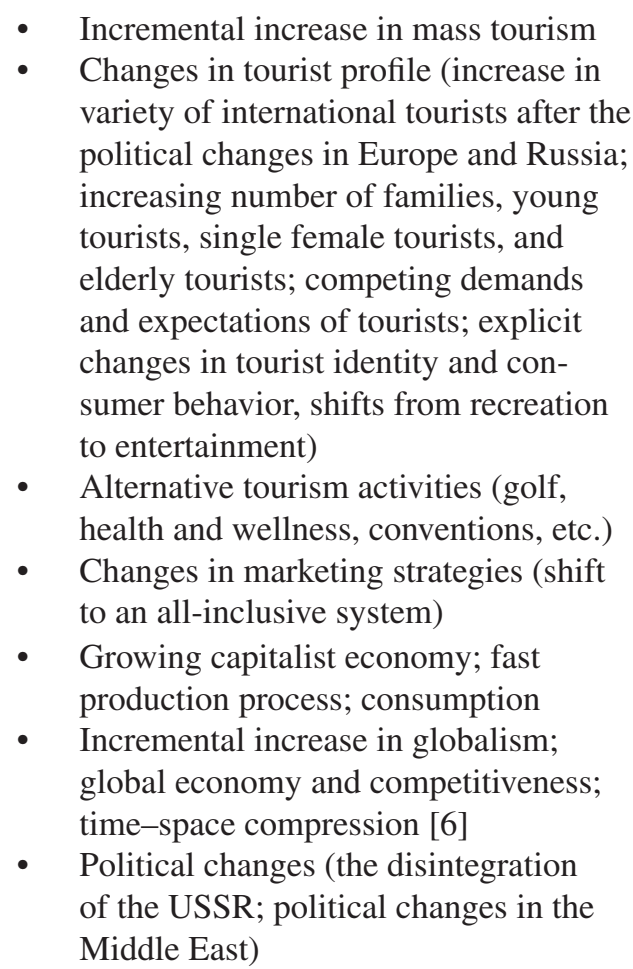 & $\begin{array}{l}\text { - Innovations toward designing } \\
\text { - } \quad \text { different' } \\
\text { Designing regardless of context; losing } \\
\text { the 'sense of place'; creating spaces } \\
\text { that can be 'everywhere but nowhere' } \\
\text { - Shift from local images to popular } \\
\text { images } \\
\text { - Increasing number of activity and } \\
\text { entertainment areas } \\
\text { - Expanded capacity to meet tourist } \\
\text { demand } \\
\text { Improving family concepts due to } \\
\text { increasing number of families traveling } \\
\text { Increase in variety of night shows and } \\
\text { activity spaces } \\
\text { Designing new consumption places and } \\
\text { images } \\
\text { - Shortening economic life (planning on } \\
\text { 10-15-year cycles) } \\
\text { Expanded capacity to meet new tourist } \\
\text { demand } \\
\text { Pursuit of different images to survive in } \\
\text { global competition }\end{array}$ \\
\hline
\end{tabular}




\begin{tabular}{|c|c|c|}
\hline & Areas of change & Impacts of change on resort hotel design \\
\hline 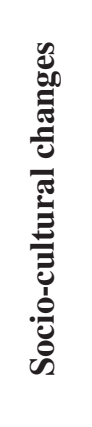 & $\begin{array}{l}\text { Increasing tendency toward } \\
\text { individualism } \\
\text { Changes in the tourist experience; } \\
\text { experiencing the dream; authenticity; } \\
\text { escapism; booming 'experience' } \\
\text { economy [15] } \\
\text { Increasing amount of leisure time and } \\
\text { activities } \\
\text { - Competing demands and expectations } \\
\text { of tourists }\end{array}$ & $\begin{array}{l}\text { Designing trendy spaces to meet } \\
\text { popular expectations } \\
\text { Designing new consumption places and } \\
\text { images } \\
\text { - Renovations to meet new expectations } \\
\text { of boundless new activities } \\
\text { Increase in variety of entertainment and } \\
\text { activity spaces }\end{array}$ \\
\hline 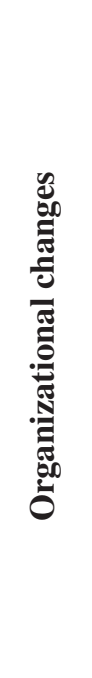 & $\begin{array}{l}\text { - Increasing tendency toward branding } \\
\text { (equilibrium in marketing, lower } \\
\text { marketing cost) } \\
\text { Increasing number of chain hotels } \\
\text { (standardization, credibility, the power } \\
\text { of corporate identity) } \\
\text { - } \quad \text { Outsourcing } \\
\text { Changes in the relationship between } \\
\text { tour operators and hotel managers } \\
\text { (increasingly active role of tour } \\
\text { operators on marketing, manager's } \\
\text { bargaining power against tour } \\
\text { operators) } \\
\text { International Organization for Standards } \\
\text { (ISO; such as risk, quality, energy, } \\
\text { environmental management) }\end{array}$ & $\begin{array}{l}\text { Changing functions of spaces; flexible } \\
\text { spaces (additions to the established } \\
\text { hotels, re-designing useless spaces } \\
\text { because of outsourcing) } \\
\text { - Changes in spatial organizations to } \\
\text { meet new demands (chain hotels and } \\
\text { their specific standards, tour operators' } \\
\text { demands, additional spaces and } \\
\text { activities) } \\
\text { - Expanded capacity after organizational } \\
\text { changes } \\
\text { Renovations to meet international } \\
\text { standards } \\
\text { Changing images to meet new corporate } \\
\text { identities, renewing corporate identities } \\
\text { and related images }\end{array}$ \\
\hline 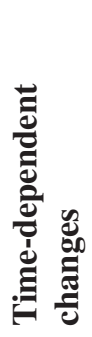 & $\begin{array}{ll}\text { - } & \text { Aging; maintenance } \\
\text { - } & \text { Technological innovations } \\
\text { - } & \text { Environmental factors; sustainability }\end{array}$ & $\begin{array}{l}\text { - Renovation of hotels } \\
\text { - } \\
\text { Tenewing of infrastructure } \\
\text { connections, pay TV, interactive TV, } \\
\text { DVDs, RFID cards, etc.) } \\
\text { Sustainable materials, impact on } \\
\text { energy usage, water savings, wellness, } \\
\text { recycling, waste decomposition }\end{array}$ \\
\hline
\end{tabular}

Baraner [31] indicates that tourists' demands for variety and innovation will increase, be polarized, and switch from the '3S' (Sea, Sand, and Sun) to the '3E' (Education, Entertainment, and the Environment) in the coming years. He also identifies the primary long-term tourism trends as sustainability, inexpensive but high-quality resorts, multiple destination vacations, exotic and authentic locations, unique experiences, adventure and excitement-focused vacations, cultural tours and activities, recreation and sports, health and wellness, and individual tours. 
These days, the majority of consumers who comprise the largest portion of the market share that prefers Antalya as a vacation destination are families traveling with children. As a result, resort hotels in the area are now being designed in to meet these families' demands by adding family guestrooms and expanding activities geared toward children. It is expected that Antalya will also see an increase in the number of elderly European tourists and single-female tourists, two groups who have begun to take up an increasing portion of the global market share. In both cases, such a demand shift would likely result in more health and wellness centers and more women-oriented activities at resort hotels [32].

Because of the substantial increase in international tourists resulting from the political changes in Europe and Russia, resort hotels have changed to meet the demands of tourists from various nationalities. German tourists tend to prefer vacationing in nature, and middle-aged tourists are more likely to return to locations they have already visited. Affluent British tourists tend to prefer golf resorts. Russians visiting areas for the first time are more likely to seek out unique experiences and locations as they have recently switched to a Liberal Economic system and have desire to see new places [27].

After the millennium, the most important change seen in resort hotel design was a shift from the FB or HB systems to all-inclusive system. Before the all-inclusive system, resorts were designed to maximize wthe amount of tourist consumption. As resort hotels have switched to all-inclusive system, they have experienced a new need to control the amount of consumed free services. Rather than designing free-service areas like restaurants and bars at the most desirable and attractive locations on the resort grounds, architects now focus on constructing health and wellness centers and shopping areas, both locations in which consumers pay additional fees.

One of the major changes in the hotel management system is the tendency toward outsourcing certain services. Outsourcing allows resorts the opportunity to spend less space on service areas such as kitchens, laundries, night shows, and activity spaces. Thus, these spaces are made more available for transformations, and are designed with new and innovative aspects in mind.

It is no longer enough for resort hotels simply to be comfortable. Furthermore, international standards such as ISO 9000 and ISO 14000 must be achieved [33]. As European consumers are increasingly seeking resorts that achieve these standards, resort hotels that aim to achieve these standards will earn more of the market share. These standards also require changes in services offered, infrastructure, materials, systems, and spatial organizations.

Change in tourism and the impacts of such changes on architectural planning and design are classified and listed in Table 2.

\subsection{Renovations and additions to resort hotels in Antalya: 2001-2012}

Besides the tremendous number of new construction, most existing resort hotels completed their 10 -year renovation cycle and needed to change. In order to retain the market advantage of offering new, high-quality, modern resort hotels, the Turkish tourism industry turned its attention toward renovations in the 2000s [34].

Tourism in Antalya peaked in the years 1994-1995 and 1999-2000. This acceleration encouraged developers to renovate their hotels and expand their recreation facilities. In 2002, tourism research showed that $27 \%$ of hotels in Turkey began to slip from international standards, and 550 hotels were over 10 years old and in need of renovation. Of the 550 hotels that were built in the 1990s, 178 in Antalya needed urgent renovations due to aging and changes in tourism.

This research focuses on the resort hotels built between 1987 and 1997 in Antalya. Twelve resort hotels that were renovated between 2001 and 2012 were selected and surveyed by site 
visits, web search, and/or archival research, and all renovated spaces were analyzed in order to explore the level and types of changes made in the new designs [4].

\subsubsection{Renovations in 2001}

The renovations of these selected 12 resort hotels in 2001 were analyzed for this research (Table 3 ).

- Guestrooms: Carpets, bed covers, and furniture were renovated in guestrooms due to the aging problem faced by 10 of the 12 resort hotels. Only the bathrooms were renovated at the Hotel A and Hotel H. Seven hotels renovated their suites as well as their standard guestrooms.

- Lobby: Because the lobby is the first resort space that guests experience, it creates the initial image of the resort in guests' minds. Consequently, hotel developers give high priority to the renovation of their lobbies. The reception desk, concierge, and lounge areas were renovated at seven of the surveyed resort hotels. Shopping areas were also added around the lobby of the Hotel F.

- Restaurants: At five of the hotels, the main restaurants and their kitchens were renovated in order to achieve HACCP standards. Changes to the restaurants and bars were also required due to a general shift to an all-inclusive system designed to control the amount of food consumed.

- Leisure and entertainment: Four hotels renovated their theaters, night shows, and activity spaces; two hotels renovated their nightclubs. Swimming pools and pool bars were renovated at three of the 12 hotels; four hotels added children's pools, and three hotels added activity pools.

- Sports: Most of the surveyed hotels provide areas for sports activities such as mini-soccer, basketball, volleyball, handball, and table tennis, as well as tennis courts and water sports centers. Besides these activities, two hotels added bowling halls, one hotel added archery, one hotel added soccer, and two hotels added golf courses.

- Health and wellness: Most hotels surveyed have Turkish baths, saunas, fitness centers, and indoor pools. Hotel A renovated its sauna and Turkish bath, and added massage rooms.

This study determined that the guestrooms, the main restaurant, and the lobby were the primary renovation areas due to the aging. Hotel developers erred on the side of caution in 2001 and focused mostly on vital renovations. However, in the subsequent years, developers have tended toward adding more activity and entertainment spaces, and expanding the services offered by the resorts [4].

\subsubsection{Renovations and additions between 2002 and 2005}

The renovations and additions to these 12 resort hotels between the years 2002 and 2005 were also analyzed for this research. The most important difference between the renovations in 2001 and the later renovations was the expanded variety of services and activities offered. To survive in the competitive resort environment, to meet tour operators' and tourists' demands, and to increase market share, the surveyed hotels both renovated their spaces and expanded their activities (Table 4).

- Guestrooms: One of the biggest changes was the expansion of the 'family' concept. Children's spaces and activities were expanded, due to an increasing number of families visiting the hotels. In this sense, five hotels added family rooms, one hotel added junior suites, one hotel added deluxe guestrooms, and two hotels added villas. Besides these additions, the standard rooms were renovated at four of the 12 surveyed hotels.

- Lobby: Three hotels renovated their lobby spaces in order to provide the resorts with updated images and a trendier look.

- Restaurants: Main restaurants and their kitchens were renovated at four hotels. Six hotels added a'la carte menus, and four hotels added children's restaurants. 


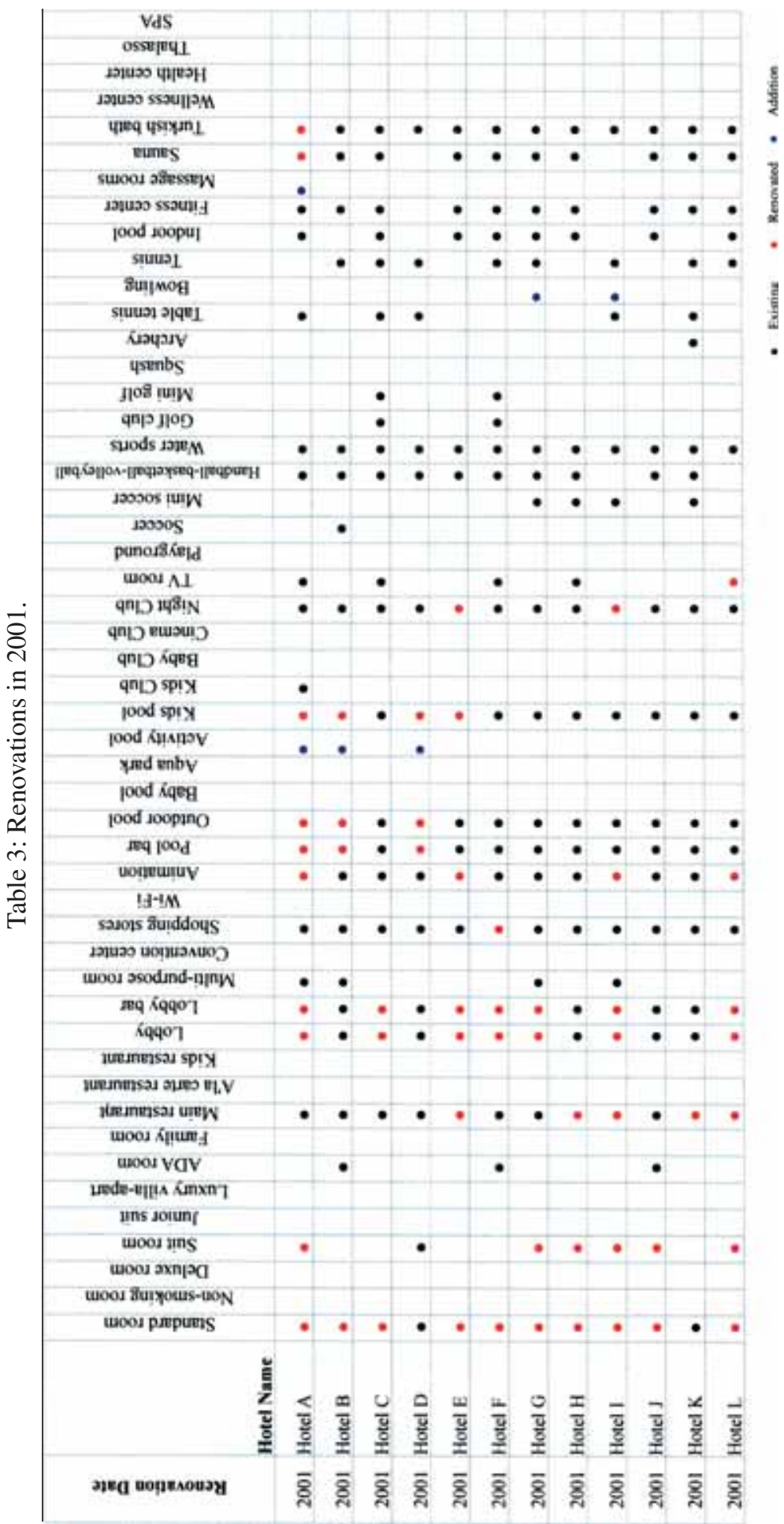




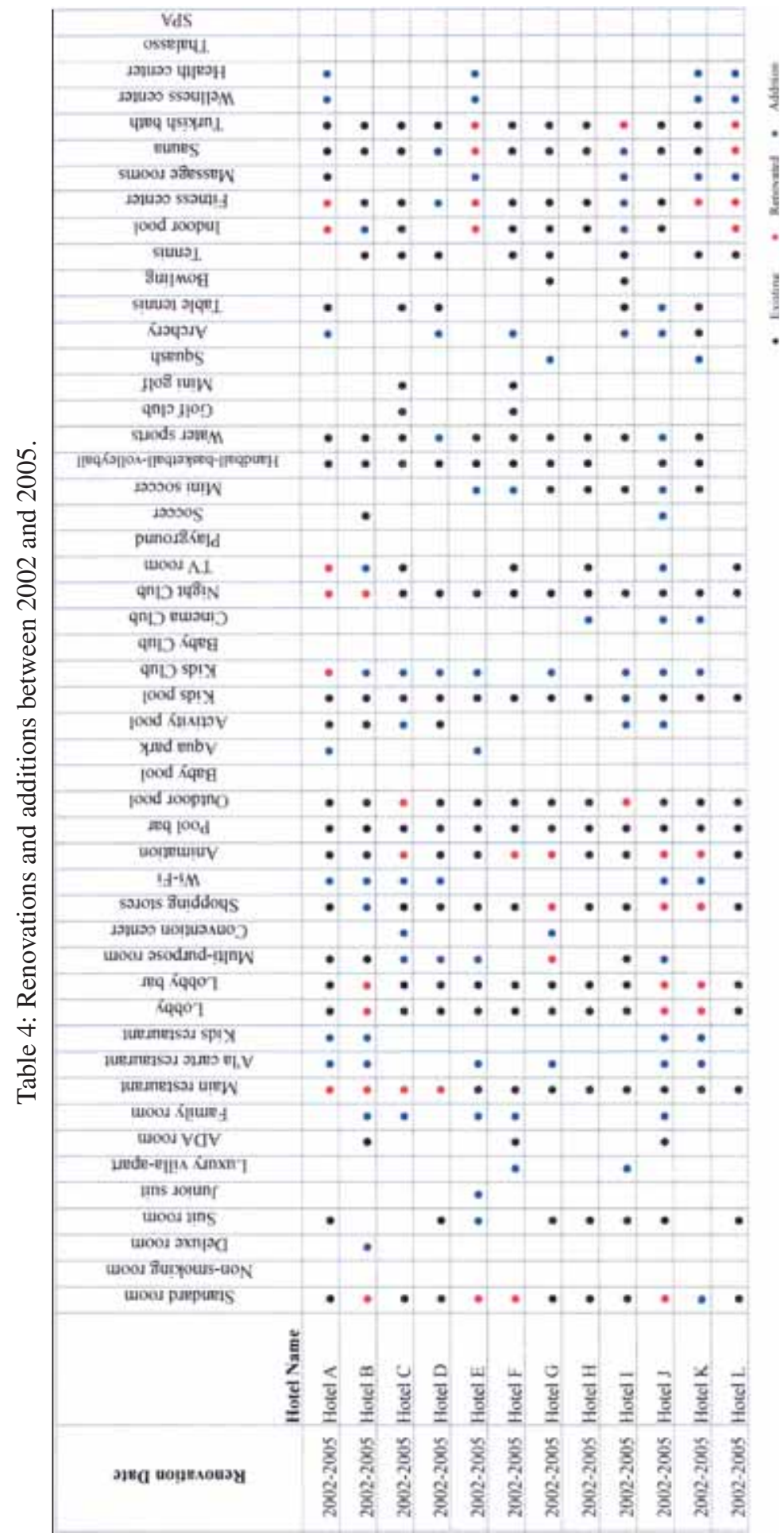


- Leisure and entertainment: Five hotels renovated their theaters, night shows, and activity spaces, and two hotels renovated their nightclubs. Swimming pools and pool bars were renovated at two of the 12 surveyed hotels, three hotels added activity pools; two hotels added indoor pools; and two hotels opened new aquapark centers.

- Sports: Besides other activities, five hotels added archery, one hotel added soccer, three hotels added mini-soccer, and two hotels added squash tennis.

- Health and wellness: Turkish baths, saunas, massage rooms, and indoor pools were renovated at five hotels. Health and wellness centers were established with the new additions such as Finnish baths, bath therapy centers, steam rooms, aromatherapy rooms, areas for stone massages, solariums, and spaces for face and body care.

- Activities: Four hotels added multipurpose meeting rooms, and four hotels renovated existing rooms of this type. Hotel $\mathrm{C}$ and Hotel $\mathrm{G}$ expanded their recreation facilities and established congress centers. Three hotels renovated their shopping centers, and one hotel added more shops.

- Children's Activities: Nine hotels changed their core concept to a 'family' concept. One hotel renovated its children's club, and eight hotels added new clubs. Hotel J added a small zoo in order to expand the activities offered for children.

- Technology: Six hotels implemented Wi-Fi systems in order to provide their guest's access to the Internet.

The renovations between 2002 and 2005 were mostly focused on expanding facilities and activities (a'la carte restaurants, activity pools, aquaparks, shopping centers, congress centers, nightclubs, night shows and activity spaces, sports, health and wellness centers), and improving upon the 'family' concept (adding suites, family rooms, villas, children's clubs, activities, and pools) [4].

\subsubsection{Additions between 2006 and 2012}

Between 2006 and 2012, resort hotels continued to expand the amenities they offered. The primary reason for this transformation was so that these hotels would be able to compete with newer and newly renovated hotels in the area, and so that they might increase their bargaining power with tour operators (Table 5).

- Guestrooms: During this 7-year period, most of the hotels widened the variety of rooms they provided. The 'family concept' continued to gain popularity, and six more hotels added family rooms. There also was an important increase in the number of nonsmoking rooms, and five hotels added dedicated nonsmoking rooms. Besides the addition of these rooms, three hotels added ADA rooms, three others added luxury villas, one hotel added junior suites, three hotels added suite rooms, and three others added deluxe rooms. Eleven of the 12 hotels examined now have family rooms.

- Restaurants: Six more hotels added different a'la carte restaurants, and two hotels added children's restaurants. All hotels now provide the variety of bars and international kitchens, offering Italian, Mexican, Chinese, Japanese, and French dishes, among others.

- Leisure and entertainment: Eight hotels added aquaparks, five hotels added activity pools, one hotel added an indoor pool, and four hotels added baby pools.

- Sports: All hotels expanded the sports activities they provided. Besides the other activities offered, two hotels added soccer fields, three added mini golf courses, three hotels added squash courts, one hotel added an archery range, six hotels added table tennis, three hotels added bowling alleys, and four hotels added tennis courts.

- Health and wellness: Spas, massage rooms, and health and wellness centers became very trendy 


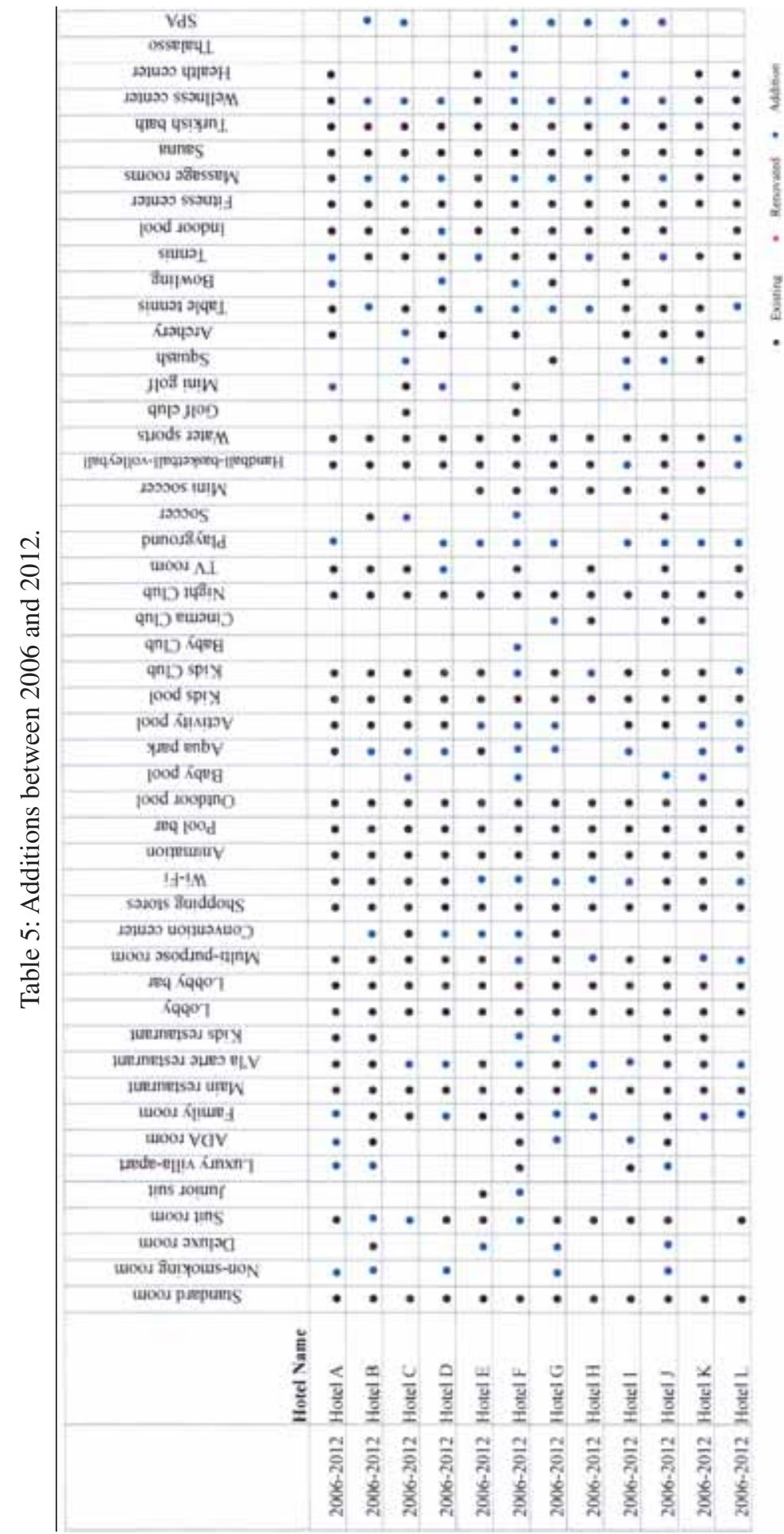


in the last 6 years. Seven hotels added spas, eight hotels added wellness centers, two hotels added health centers, and seven hotels added massage rooms.

- Activities: Four hotels added multipurpose meeting rooms, and four other hotels added convention centers. Besides meeting activities, one hotel added a cinema, and one hotel added a TV room.

- Children's activities: Three hotels added kids' clubs, one hotel added a baby club, and nine hotels added playgrounds. All 12 hotels now provide club services designed for children.

- Technology: Six hotels implemented Wi-Fi systems to provide their guests with access to the Internet.

- Sustainability: Six out of the 12 hotels studied developed sustainable environment and productivity programs, got certified in this area, and were awarded citations by various environmental groups. Hotel $\mathrm{G}$ has included new environmental precautions such as solar energy, natural gas, waste decomposition, recyclable materials, energy savers in the rooms, and sensor devices for both electricity and water.

The case studies indicate that the major renovations in 2001 were due to the 'aging' problem faced by many hotels, while renovations between 2002 and 2005 were more focused on expanding facilities and activities, and improving upon the 'family concept'. Additions between 2006 and 2012 also showed a trend toward a focus on entertainment; as families kept growing, resort hotels kept expanding. This study also has seen an improving trend toward sustainability.

Tables 3-5 illustrate the dramatic transformation of hotels in the last decade; such a transformation can be witnessed merely by looking at the changes in the number of amenities and activities hotels now provide. All of the changes in the spatial organization of hotels, as well as the increase in new additions and functions, have increased the difficulty of the design problem.

\section{CONCLUSION}

The case studies used for this research reveal the dramatic consumption and transformation of resort hotels in Antalya/Turkey. The transformation can be described as follows:

- In the last 11 years, resort hotels have expanded the variety of the types of rooms they offer. They used to offer only standard and suite rooms. However, due to tourist demand, almost all resort hotels now offer family rooms, and most offer deluxe rooms, luxury villas, and nonsmoking rooms. These changes show a trend toward a 'family concept', as well as an increased focus on luxury.

- In 2002, none of the resort hotels offered an a'la carte restaurant; they only had main restaurants at their properties. Now, all offer four to five different a'la carte restaurants with international kitchens and bars. By providing tourists with different dining options, these hotels seek to keep their guests inside the resort complex at all times, accordingly encouraging their guests to consume more.

- Aquaparks, indoor pools, and activity pools have become very popular in the last 11 years. Resorts also have started adding baby pools, due to family-oriented tourists' demands. Besides these pool areas, resort complexes also now include theaters, nightclubs, shows, and other entertainments facilities to meet tourist expectations regarding entertainment.

- All of the resort hotels studied in this research have expanded their sports facilities. Sporting facilities no longer include only water sports, tennis, and basketball courts, but now also include golf, soccer fields, mini golf courses, squash courts, archery ranges, bowling alleys, billiards tables, and the like. Hotel complexes also have added facilities for children such as clubs for children and babies, children's restaurants, playgrounds, and amusement parks, a direct response to the new 'family resort' concept. 
- In the last decade, health and wellness have become more important, especially among women and the elderly. In response to an increase in the number of these types of people traveling, resort hotels have begun adding new facilities to their properties in an effort to meet expectations regarding health and wellness. Now, all of the resort hotels studied here have Turkish baths, saunas, massage rooms, and health and wellness centers.

- Today, all of the resort hotels studied here have multipurposed meeting rooms, and most have convention centers; this is due to an increasing demand for convention facilities. Some of these hotels also have added cinemas and TV rooms.

- In 2002, none of the resort hotels examined for this research provided Internet connections in their guestrooms and/or public areas; instead, they directed their guests to Internet cafes. Now, all resort hotels provide Wi-Fi services at their properties, in order to meet tourist demand in this area.

- Sustainability is an improving trend in all areas of life. Today, most resort hotels have developed sustainable environmental programs, had renovations done in an effort to reduce energy use, and have been certified as environmentally friendly with various different environmental protection groups.

The case studies conducted for this research indicate that the rapid consumption and transformation of resort hotels is now an international phenomenon. The challenge is how to manage these additions within a limited building footprint. In some cases expansion is possible, but in some other situations transformations must be made within the existing building, and this requires spatially flexible and sustainable designs. Architects should begin seeing economically and spatially sustainable, unique, and flexible solutions emerging from this competitive environment, where design concerns and functional and spatial necessities are constantly changing.

Today, research has shown us that the demands associated with resorts now far surpass a simple need for accommodation. Consumers now seek fun, adventure, and unlimited activity from the resort at which they chose to stay. Although new thematic resorts may attract customers with their themed image, they are far from fulfilling this demand over a sustained period. Without a doubt, it is now necessary for hotel and resort complexes to be distinctive, present a 'new' image, and offer modern and trendy facilities in order to stake a genuine claim in the market, or even to survive. However, it has also become obvious that resort hotels built based on a concept of formal replicas and themes may fade rapidly from the consumer's imagination, and thus lose their commercial value because they may quickly become perceived as boring. Conversely, those resorts that follow the newest trend of diversity (in terms of the facilities they offer) without conceding the architectural quality and uniqueness will prove to be more successful in the long run [31].

As Riewoldt [15] states in his book, the economic life of hotels is getting shorter and shorter, and there is an increasing demand for the 'new'. This statement emphasizes the new, more rapid consumption of hotels and their overall state of temporariness. Within this framework, designers are now called upon to envision this temporariness and reflect it in their designs, developing more flexible plans that can more easily comply with the shifting desires of tourist consumers. This need for flexibility and a continuous transformation of the functional spaces illustrate how that now it is not really possible to assess these ever-changing resort hotels within a framework of conventional spatial design; as a result, a new building typology must be defined. In this new type, design criteria must differ from that which, in the past, has been used by other building types; these new resort complexes should be planned for continuous transformation and adaptation to accommodate the changing facilities, types of recreation, games, and adventure activities expected by today's vacationing consumers. 
Resort hotels also differ from other types of buildings by virtue of their design process; this process will by necessity involve many variables and a precise detection of the design input, as well as the demands and expectations of the tourist consumer. An accurate analysis of the design process will be critical to the success of the facility. First, the design process will require a strong collaboration between the investors, managers, and designers in all stages, including strategic planning, design, and construction. Moreover, the design process should not end with the completion of the building, but instead must continue throughout the building's lifetime; it must parallel the changing landscape of consumer demand. As a result, design strategies should be developed by means of a flexible approach with an eye toward the constantly changing types of tourist consumption [4].

This research also predicts that even the requirements of these changes may be exceeded by the tourists of the future. Today's children create virtual computer cities, and such a sense of simulation could easily enter all areas of life; hotels of the future could be designed in a like manner, with different spatial constructs such as simple, sustainable, empty infrastructures that could easily be transformed into any type of space. In this sense, the discussions should focus on whether or not it would truly be possible to design economically and spatially sustainable, but also functionally flexible spaces and systems where the fixed construction is minimalized and the spaces (except for the vertical circulation cores and installation shafts) are modular, demountable, modifiable, and convertible.

In conclusion, today's architect is being challenged to search for design quality, uniqueness, and flexibility while simultaneously accommodating the constantly shifting nature of the design input, as well as the functional and spatial requirements of resort hotels. As Collins states, 'At the end of the day, the success of the hotel design will be judged by its longevity as much as by any other criteria. Designers will face a constant challenge to create something that is both new and timeless' [19].

\section{REFERENCES}

[1] Lawson, F., Turizm Gelişmesi: Mücadele ve Fırsatlar Temel Esaslara Dayalı Bildiri, 2000 Yılına Doğru Turizm Mimarlı̆̆g Paneli, Boğaziçi Üniversitesi, Istanbul, 22 Nisan 1993, pp. 3-9, 1995.

[2] MacCannell, D., The Tourist: A New Theory of the Leisure Class, Schocken Books: New York, 1976.

[3] Tanyeli, U., Kitle Turizmi ve 'Yok-Mekan' Mimarlığı. Arredamento Mimarlık, 171, pp. 74-77, 2004.

[4] www.witpress.com, ISSN 1743-3541 (on-line) WIT Transactions on Ecology and the Environment, Vol. 161, (C) 2012 WIT Press. doi: http://dx.doi.org/10.2495/ST120271

[5] Richter, J., The Tourist City Berlin: Tourism and Architecture, Braun Publishing: Braun: Salenstein, 2010.

[6] Urry, J., Consuming Places, Routledge: London and New York, pp. 131-132, 1995.

[7] Zukin, S. \& Maguire, J.S., Consumers and consumption. Annual Review of Sociology, 30, pp. 173-197, 2004. doi: http://dx.doi.org/10.1146/annurev.soc.30.012703.110553

[8] Baudrillard, J., Tüketimin Tanımına Doğru, Mimarlık ve Tüketim, Boyut Yayın Grubu: Istanbul, pp. 67-73, 2002.

[9] Süer, D. \& ve Yılmaz Sayar, Y., Küresel Sermayenin Yeni Tüketim Mekanları Lüks Konut Siteleri, Mimarlı ve Tüketim, Boyut Yayın Grubu: Istanbul, pp. 39-67, 2002.

[10] Zengel, R., Kitle Turizminden Alternatif Turizme, Tatil Köyü - Butik Otel Ikilemi. Arredamento Mimarlık, 161, 2003.

[11] Sagocak, M., Insanın Nesnelerle Ilişsisi ve Tüketim Olgusu. Yapı, 261, pp. 101-104, 2003.

[12] Adham, K.N., Tourism, authenticity, and hyper-traditions: the case of Kafr Al-Gouna, Egypt. Traditional Dwellings and Settlements Review, 18(1), p. 61, 2006.

[13] Songkhla, S.N., Local culture in the global village: authenticity in a Tai Tourist Town. Traditional Dwellings and Settlements Review, 18(1), p. 62, 2006. 
[14] Baudrillard, J., Simulacra and Simulation, The University of Michigan Press: Ann Arbor, p. $12,1981$.

[15] Riewoldt, O., New Hotel Design, Watson-Guptill Publications: New York, p. 11, 2002.

[16] Altun-Doğaner, S., Kültürel Miras: Tüketilemeyen Turizm, Diyarbakır 1. Uluslararası Suriçi Sempozyumu Bildiriler Kitabı, 20-22 Nisan 2006: Diyarbakır, pp. 95-99, 2006.

[17] Yirtici, H., Tuketimin Mekansal Orgutlenmesinin Ideolojisi, Mimarlik ve Tuketim, Boyut Yayin Grubu: Istanbul, pp. 9-39, 2002.

[18] Shaw, G. \& Williams, A.M., Tourism and Tourism Spaces, Sage Publications: London, 2004.

[19] Collins, D., New Hotel - Architecture and Design, Conran Octopus Limited: London, pp. 213-215, 2001.

[20] Reimer, G., Packing dreams: Canadian tour operators at work. Annals of Tourism Research, 17, pp. 501-512, 1990. doi: http://dx.doi.org/10.1016/0160-7383(90)90023-K

[21] Miroglu, E.A., Hyper-tourism in the Mediterranean Riviera of Turkey. Traditional Dwellings and Settlements Review, 18(1), p. 84, 2006.

[22] Tsui, C.M.C., Learning from Las Vegas! The recent development of Macau's Mega- Casino/ Resorts. Traditional Dwellings and Settlements Review, 18(1), p. 62, 2006.

[23] Hassanien, A. \& Baum, T., Hotel product renovation as a product modification marketing tool. Shaping the Future of Tourism: Mix, Match and Move, Proceedings of the 7th Annual Conference of the Asia Pacific Tourism Association (APTA), ed. C. Gatchalian, C.S. Vincent \& C. Reil, Makati, 2001.

[24] Rutes, A.W., Penner, R.H. \& Adams, L., Hotel Design: Planning and Development, Norton \& Company: New York, 2001.

[25] Ayik, O., Oral Interview. (Director of Association of Mediterranean Hoteliers - AKTOB), 2005.

[26] Vickers, G., 21st Century Hotel, Laurence King Publishing: London, pp. 8-11, 2005.

[27] Arabaci, H., Oral Interview. (Manager of Asteria Hotels \& Resorts), 2005.

[28] Orhon, O., Oral Interview. (Architect, Board member Aksoy Group), 2005.

[29] Ministry of Culture and Tourism - Antalya http://www.antalyakulturturizm.gov.tr/belge/1-63048/kultur-turizm-istatistikleri.html (accessed 18 March 2012).

[30] Doganer, S., Representing local identities in resort hotels - a case study in Antalya. 2011 ACSA Fall Conference 'Local Identities/Global Challenges', October 6-8, 2011, Houston, TX, 2011.

[31] Baraner, H., Avrupa Turizm Talebinde Gelisme Egilimleri ve Antalya. Vizyon, 202, pp. 8-15, 2004.

[32] Yetis, M., Oral Interview. (Manager of TUI), 2005.

[33] Kars, K., Antalya Turizminde 2004 Yılı Degerlendirmesi ve Gelecek Vizyonu, Antalya Ticaret ve Sanayi Odası Raporu, Antalya, 2004.

[34] Akdag, B.O., Simdi Tesislerimiz Bir Numara, ya Yarin! Tourism World, 3, pp. 10-15, 2003. 